Jeffrey P. Chvilicek MD, ${ }^{*}$ Barbara J. Hurlbert MD,* Gary E. Hill MD* $†$

\section{Diuretic-induced hypokalaemia inducing torsades de pointes}

Torsades de Pointes (TP) is an unique type of ventricular tachycardia, characterized by QRS complexes of changing amplitude preceded by a prolonged $(>500 \mathrm{msec}) \mathrm{QT}$ interval, most frequently observed with anti-arrhythmic drug therapy and electrolyte disturbances. ${ }^{1}$ While hypokalaemia has been commonly associated with $\mathrm{TP}^{2}{ }^{2}$ it is usually chronic hypokalaemia with concomitant antiarrhythmic drug administration and/or hypomagnesaemia. $^{3}$ While many episodes of TP terminate spontaneously, some degenerate to a more typical ventricular fibrillation resulting in death. ${ }^{4}$ We report a case of TP occurring during orthotopic liver transplantation in a child caused by an acute extracellular hypokalaemia with normal serum magnesium concentration and no previous anti-arrhythmic drug exposure.

Les torsades de pointes (TP) sont un type particulier de tachycardie ventriculaire. Elles sont associées à l'allongement acquis ou congénital de lintervalle $Q T$. Plusieurs observations ont décrit des TP après l'allongement du QT consécutif à une hypocalcémie, une hypomagnésémie ou une hypokaliémie. Les auteurs rapportent une hypokaliémie extravasculaire dinstallation rapide sans association à d'autres dérangements électrolytiques capables d'allonger le $Q T$ et qui a été suivie de TP. C'est là la première description de TP causées par une hypokaliémie extravasculaire aiguë. Comme les interventions anesthésiques provoquent souvent des baisses rapides du potassium extracellulaire f'administration de diurétiques, de catécholamines, dinsuline, lhyperventilation), cette observation signale le risque de ces manoeuvres relativement à la genèse des arythmies.

\section{Key words}

COMPLICATIONS: arrhythmia, hypokalaemia;

HEART: arrhythmia, torsades de pointes;

IONS: potassium.

From the Departments of *Anesthesiology and †nternal Medicine, University of Nebraska Medical Center, Omaha, Nebraska.

Address correspondence to: Dr. Barbara J. Hurlbert, University of Nebraska Medical Center, Department of Anesthesiology, 600 S. 42nd Street, Box 984455, Omaha, NE 68198-4455.

Accepted for publication 3 August, 1995.

\section{Case report}

A four-yr-old $18 \mathrm{~kg}$ caucasian boy was scheduled for orthotopic liver and small bowel transplantation because of cirrhosis secondary to short bowel syndrome. No symptoms of central nervous system dysfunction were observed. Preoperative laboratory values included a serum potassium of $3.9 \mathrm{mEq} \cdot \mathrm{L}^{-1}(3.5-4.7$ normal) and magnesium of $2.3 \mathrm{mg} \cdot \mathrm{dl}^{-1}(1.7-3.0 \mathrm{normal})$. There was no history of arrhythmia or prolonged QT interval, or family history of sudden death. A corrected QT interval (QTc) of $370 \mathrm{msec}$ was measured preoperatively (Figure A). After uneventful induction and maintenance of anaesthesia with isoflurane and muscle relaxation with pancuronium, the native liver was excised and the donor liver placed. During the anhepatic phase, the urine output was noted to be minimal, so furosemide, $15 \mathrm{mg} i \mathrm{i}$, was given. During donor graft placement, the aorta was crossclamped above the renal arteries for a total of $\mathbf{4 0} \mathrm{min}$. Following unclamping, anuria was noted. Furosemide, $180 \mathrm{mg}, \dot{w}$ in divided doses was given over three hours with no effect. At that point, the Foley catheter was found to be occluded. Upon recatheterization, 2.71 urine were measured over the ensuing $2 \frac{1}{2} \mathrm{hr}$. Over the same time, serum potassium concentration decreased from 3.9 to 2.9 $\mathrm{mEq} \cdot \mathrm{L}^{-1}$, while serum magnesium concentration remained unchanged at $2.3 \mathrm{mg} \cdot \mathrm{dl}^{-1}$. Serum ionized calcium concentrations during this time were 1.17 to 1.18 $\mathrm{mmol} \cdot \mathrm{L}^{-1}$ (1.18 to 1.30 , normal), and arterial blood $\mathrm{pH}$ 


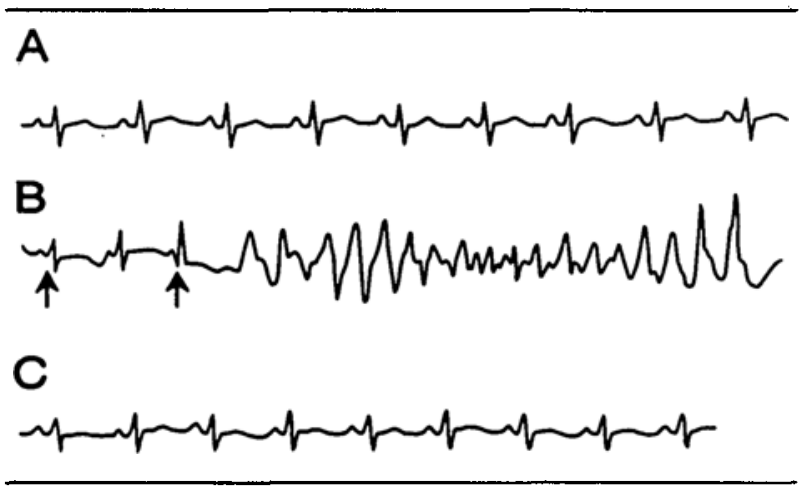

FIGURE Electrocandiogram obtained before surgery demonstrating sinus beats with a corrected QT interval (QTc) of $370 \mathrm{msec}$ (Figure A). Intraoperative electrocardiogram obtained demonstrating sinus beats with prolonged corrected QT interval (QTc) (t) progressing to torsades de pointes (TP) ventricular tachycardia (Figure B). Electrocardiogram obtained after termination of TP showing a normal QTc (Figure C).

was consistently between 7.38 to 7.45 . The heart rate was never observed to be $<100 \mathrm{bpm}$. In spite of potassium replacement ( $40 \mathrm{mEq}$ over five hours), $51 / 2 \mathrm{hr}$ after revascularization of the liver and small bowel and during biliary reanastomosis, a prolonged corrected QT interval (QTc) of $600 \mathrm{msec}$ was noted, followed rapidly by TP of $5.6 \mathrm{sec}$ duration resulting in severe systemic hypotension (Figure B). Treatment with lidocaine $40 \mathrm{mg} i v$ magnesium $400 \mathrm{mg} i v$ and $\mathrm{KCl}(10 \mathrm{mEq} \dot{w}$ over $20 \mathrm{~min})$ restored sinus rhythm with a QTc of $380 \mathrm{msec}$ (Figure C).

Oesophageal temperature measurement remained $>35^{\circ} \mathrm{C}$ throughout the TP and the entire surgical procedure. The remainder of the case was uneventful.

\section{Discussion}

Hypokalaemia predisposes to ventricular arrhythmias following myocardial infarction ${ }^{5}$ and during epinephrine infusion in dogs. ${ }^{6}$ Electrophysiological studies characteristically demonstrate a depolarization hump during phase 3 repolarization (early after depolarization, or EAD), as being the underlying electrical event responsible for TP. ${ }^{2}$ Phase 3 repolarization corresponds to the $T$ wave of the surface ECG; therefore, an EAD would correspond to

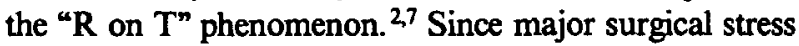
is known to be associated with elevated plasma epinephrine concentrations, ${ }^{8}$ the pro-arrhythmic effects of diuretic-induced hypokalaemia was possibly potentiated by an epinephrine-induced hypokalaemia. ${ }^{5,6} \mathrm{Kwon}$ et al. ${ }^{9}$ reported that an acutely hypokalaemic (induced by hyperventilation) rat model was surprisingly more resistant to the arrhythmogenic effect of an epinephrine infusion than was a normokalaemic control group.

Magnesium replacement acts by shortening the QT in- terval, ${ }^{10}$ and suppressing EAD's. ${ }^{11}$ In chronic hypokalaemia a $42 \%$ incidence of hypomagnesaemia has been reported. ${ }^{12}$ Ventricular arrhythmias are commonly associated with combined hypokalaemia and magnesaemia. ${ }^{13}$ Under these conditions, magnesium and potassium replacement are required for ventricular arrhythmia control. " While TP has been commonly reported with normal serum magnesium concentrations, ${ }^{10}$ exogenous magnesium administration has been shown to be effective in terminating TP despite normal serum levels. ${ }^{14}$ Fiaccadori et al. found no correlation between muscle and serum magnesium concentrations in chronically ill patients, ${ }^{15}$ thus a normal serum magnesium concentration may be found with total body hypomagnesaemia.

The extracellular potassium concentration is the primary determinant of resting membrane potential in human cardiac muscle; decreased extracellular potassium will prolong action potential duration; i.e., prolonged QT interval, as well as increase the rate of spontaneous phase 4 depolarization (increase automaticity), and hyperpolarize the resting membrane potential. ${ }^{16,17}$ In the potassium deficient state, extracellular potassium decreases more than intracellular ${ }^{7}$ and, as described by the Nernst equation, ${ }^{18}$ results in membrane hyper-polarization. Isolated chronic hypokalaemia is known to induce $\mathrm{TP},{ }^{2,18}$ but this is the first report demonstrating that a rapid onset extracellular hypokalaemia may also induce TP. Curry $e t$ al. ${ }^{19}$ reported two cases of TP associated with isolated chronic hypokalaemia, one secondary to hyperaldosteronism, the other due to familial periodic paralysis. Tamura et al. ${ }^{20}$ reported a single case of TP with isolated hypokalaemia. Soroker $e t$ al. ${ }^{21}$ reported two cases of intraoperative TP associated with combined chronic hypocalcaemia and rapid onset hypokalaemia. The first two ${ }^{19,20}$ of these case reports fail to report serum magnesium concentrations, while one ${ }^{20}$ report was complicated by simultaneous digitalization.

Complications described with furosemide have been generally related to its primary effect of sodium, potassium, magnesium, and water loss secondary to inhibition of active chloride transport in the loop of Henle. ${ }^{22}$ Large dose $\left(7 \mathrm{mg} \cdot \mathrm{kg}^{-1}\right)$ furosemide administration has little direct cardiovascular effect, ${ }^{23}$ while $1.5 \mathrm{mg} \cdot \mathrm{kg}^{-1}$ has been demonstrated to be without cardiovascular effects while causing a rapid $(15 \mathrm{~min})$ reduction of plasma potassium concentration. ${ }^{23}$ While supraventricular tachycardia due to furosemide treatment per se (without secondary electrolyte alteration $)^{24}$ has been observed, no report has demonstrated that ventricular arrhythmias have been induced by furosemide.

In summary, this is the first description of a rapid onset, isolated, extracellular hypokalaemia resulting in an acquired prolonged QTc followed rapidly by TP. Even- 
with a normal serum magnesium concentration, exogenous magnesium helped restore a normal QTc and terminate TP. This report serves as a warning that a rapid decrease in extracellular potassium concentration with no other risk factors may precipitate TP.

\section{Referenes}

1 Banai $S$, Tzivoni $D$. Drug therapy for torsade de pointes. Cardiovasc Electrophysiol 1993; 4: 206-10.

2 Shimizu W, Tanaka K, Suenaga K, Wakamoto A. Bradycardia-dependent early afterdepolarizations in a patient with QTU prolongation and torsade de pointes in association with marked bradycardia and hypokalaemia. Pacing Clin Electrophysiol 1991; 14: 1105-11.

3 Loeb HS, Pietras RJ, Gunnar RM, Tobin JR. Paroxysmal ventricular fibrillation in two patients with hypomagnesemia. Treatment by transvenous pacing. Circulation 1968; 37: 210-5.

4 Krikler DM, Curry PVL. Torsade de pointes, an atypical ventricular tachycardia. Br Heart J 1976; 38: 117-20.

5 Friedensohn A, Faibel HE, Bairey O, Goldbourt U, Schlesinger $Z$. Malignant arrhythmias in relation to values of serum potassium in patients with acute myocardial infarction. Int J Cardiol 1991; 32: 331-8.

6 Ajioka M, Sugiyama S, Ogawa K, Satake T, Ozawa T. Mechanism of cardiac arrhythmias induced by epinephrine in dogs with hypokalemia. J Am Coll Cardiol 1986; 8: 1373-9.

7 Singh BN, Hollenberg NK, Poole-Wilson PA, Robertson JIS. Diuretic-induced potassium and magnesium deficiency: relation to drug-induced QT prolongation, cardiac arrhythmias and sudden death. J Hypertension 1992; 10: 301-16.

8 Chernow B, Alexander HR, Smallidge RC, et al. Hormonal responses to graded surgical stress. Arch Intern Med 1987; 147: 1273-8.

9 Kwon NJ, Stolte AL, Farina JP. Hypokalemia in rats produces resistance to dysrhythmias under halothane anesthesia. J Cardiothorac Anesth 1989; 3: 532-5.

10 Tzivoni $D$, Banai $S$, Schuger $C$, et al. Treatment of torsades de pointes with magnesium sulfate. Circulation 1988; 77: 392-7.

11 Keren A, Tzivoni $D$. Magnesium therapy in ventricular arrhythmias. Pacing Clin Electrophysiol 1990; 13: 937-45.

12 Grant HI, Yeston NS. Candiac arrest secondary to emotional stress and torsades de pointes in a patient with associated magnesium and potassium deficiency. Crit Care Med 1991; 19: $292-4$.

13 Roden DM, Iansmith DHS. Effects of low potassium or magnesium concentrations on isolated cardiac tissue. Am J Med 1987; 82 (suppl 3A): 18-23.

14 Allen BJ, Brodsky MA, Caparelli EV, Luckett CR, Iseri $L T$. Magnesium sulfate therapy for sustained monomor- phic ventricular tachycardia. Am J Cardiol 1989; 64: 1202-4.

15 Fiaccadori E, Del Canale S, Coffrini $E$, et al. Muscle and serum magnesium in pulmonary intensive care unit patients. Crit Care Med 1988; 16: 751-60.

16 Dangman KH, Danilo P, Hordof AJ, Mary-Rabine $L$, Reder $R F$, Rosen $M R$. Electrophysiologic characteristics of human ventricular and purkinje fibers. Circulation 1982; 65: 362-8.

17 Gettes $L$, Surawicz B. Effects of low and high concentrations of potassium on the simultaneously recorded purkinje and ventricular action potentials of the perfused pig moderator band. Circ Res 1968; 23: 717-29.

18 Wong KC, Schafer PG, Schultz JR. Hypokalemia and anesthetic implications. Anesth Analg 1993; 77: 1238-60.

19 Curry $P$, Fitchett $D$, Stubbs $W$, Krikler D. Ventricular arrhythmias and hypokalaemia. Lancet 1976; 2: 231-3.

20 Tamura $K$, Tamura T, Yoshida S, Inui M, Fukuhara $N$. Transient recurrent ventricular fibrillation due to hypopotassemia with special note on the $\mathrm{U}$ wave. Jpn Heart $\mathbf{J}$ 1967; 8: 652-60.

21 Soroker D, Ezri T, Szmuk P, Merlis P, Epstein M, Caspi $A$. Perioperative torsades de pointes ventricular tachycardia induced by hypocalcemia and hypokalemia. Anesth Analg 1995; 80: 630-3.

22 Koob $R$, Prasad $K$. Acute effects of furosemide on blood electrolytes and hemodynamics in dogs. Angiology 1978; 29: 463-72.

23 Poulton TJ, Bumett PS. Immediate hemodynamic effects of high-dose furosemide in normovolemic and hypovolemic dogs. Crit Care Med 1985; 13: 420-2.

24 Wilson NJ, Adderley RJ, McEniery JA. Supraventricular tachycardia associated with continuous furosemide infusion. Can J-Anaesth 1991; 38: 502-5. 